\title{
Lung Tumor Associated Antigen
}

National Cancer Institute

\section{Source}

National Cancer Institute. Lung Tumor Associated Antigen. NCI Thesaurus. Code C2224.

A tumor associated antigen derived from the cell surface antigen of lung cancer cells.

Lung tumor associated antigen could be used as a diagnostic marker or as a form of immunotherapy targeted against lung cancer cells. 